Stanisław MŁYNARSKI ${ }^{1}$, Robert PILCH ${ }^{2}$, Maksymilian SMOLNIK ${ }^{2}$, Jan SZYBKA ${ }^{2}$, Grzegorz WIĄZANIA ${ }^{2}$, Jakub LEWANDOWSKI ${ }^{2}$

${ }^{I}$ Cracow University of Technology (Politechnika Krakowska)

${ }^{2}$ AGH University of Science and Technology (Akademia Górniczo-Hutnicza)

\title{
SIMULATION-BASED FORECASTING OF THE RELIABILITY OF SYSTEMS CONSISTING OF ELEMENTS DESCRIBED BY A NUMBER OF FAILURE PROBABILITY DISTRIBUTIONS
}

\author{
Symulacyjne prognozowanie niezawodności układów \\ o elementach opisywanych wieloma rozkladami \\ prawdopodobieństwa uszkodzeń
}

\begin{abstract}
The paper presents the developed simulation model enabling the evaluation of the reliability of technical objects, which in the process of operation is subjected to several different groups of factors causing their failures. Probability distributions of failures resulting from wear and random factors are used in the developed model to estimate the time of operation of the elements and the reliability of the system. The developed model together with the appropriate computer program is a tool of significant importance for design and operational practice. It enables decision-makers to estimate the reliability of elements and the whole system before the beginning of their operation.
\end{abstract}

Keywords: simulation, reliability, causes of failures

Streszczenie: $W$ artykule przedstawiono opracowany model symulacyjny umożliwiajacy ocenę niezawodności obiektów technicznych, które w procesie eksploatacji podlegaja kilku różnym grupom czynników powodujacych ich uszkodzenia. Rozkłady prawdopodobieństwa uszkodzeń wynikających ze zużycia i czynników losowych sa $w$ opracowanym modelu wykorzystywane do prognozowania czasu pracy elementów i niezawodności układu. Model ten wraz z odpowiednim programem komputerowym stanowi narzędzie o istotnym znaczeniu dla praktyki projektowej i eksploatacyjnej. Umożliwia decydentom szacowanie niezawodności elementów oraz całego uktadu jeszcze przed rozpoczęciem jego eksploatacji. Słowa kluczowe: symulacja, niezawodność, przyczyny uszkodzeń 


\section{Introduction}

The correct operation of technical objects in the conditions of real-life use is determined by their reliability and durability. These parameters are specified at the design stage and significantly affect the use during the operation process, its costs and efficiency, which was analyzed on various objects inter alia in [1,9]. Since the modernization of technical objects by the introduction of design and material modifications changes, their reliability and durability, the prediction of these changes is a vital issue, discussed in the present paper.

Laboratory tests enable the assessment of the durability of subassemblies and parts following, for instance, the introduction of new materials from which their elements are made. What is important is the prediction of how the changes will affect the reliability of these elements during real-life operation.

For modernized objects for which the probability distributions of time to failure resulting from wear processes (determined in laboratory tests) or random factors (in use in operation conditions) are known, the reliability prediction can be performed by means of computer simulation [2, 13], and in special cases by means of analytical calculations [8]. The random variable, and time to failure of an object is such a variable and it can then be described as the lowest value from among the times obtained from all the distributions describing the probable types of failures of the object. The fundamental assumption here is the independence of the object's failures due to the mentioned factors.

To illustrate the application of this type of model, current collector contact plates of rail vehicles were used. During operation, they are subject to different imposed factors, which result in various types of failure $[10,11]$. At the same time, their correct operation is essential to guarantee the continuity of rail vehicle movement. As they are objects performing a responsible function, the contact plates undergo a cyclic inspection to assess their technical state $[3,12]$ and the materials used for their manufacturing have to meet certain requirements and undergo the appropriate tests $[4,11,14]$.

The paper presents a model for the simulation-based forecasting of the reliability of systems whose elements are described with a number of failure probability distributions to specify the reliability of contact plate used in the selected rail vehicles.

\section{Characteristics of the analyzed technical objects}

Any technical object is exposed to various factors resulting from its use. Consequently, the object's time to failure is determined by its properties, which are given in the design and manufacturing processes along with the conditions of its use and maintenance. When the failure occurrence is not described with a model in which strict determinism is assumed, traditionally, the time to failure is characterized by the distribution of its probability. This distribution concerns the events that are effects of the impact of all the above-mentioned 
factors. Then, it becomes a useful forecasting tool that allows for a (at a certain level of analyses at least) detailed examination of physical and chemical or organization processes leading to a failure of the given objects to be limited (cf. [5]). Such an approach has been known and followed in machine design and used for at least several decades (cf. [6]).

The technical object's reliability description by a number of probability distributions proposed in the paper is intended to enable the forecasting of the object's reliability at its design or modernization stage. In practice, it means the use of the tools of computer simulation of the time to failure. The most significant feature of the developed model (and computer program) is that the simulation process covers several probability distributions specified by the researcher, which describe the occurrence of failures resulting from the impacts of various types of factors. It is assumed that these impacts are independent of each other and the effects of each one of them are described with a separate probability distribution. For example, such specified groups of factors might include:

- factors associated with wear processes (described with the probability distribution of the object's durability determined by its wear),

- random factors (described with the probability distribution of the object's time to failure not resulting from wear).

The random factors can be further categorized according to their nature and described with different probability distributions.

At each iteration, the computer simulation makes it possible to grasp the moment of the object's failure as the earliest event from among all the events selected by means of the particular probability distributions (within the given iteration).

Therefore, the object described with many probability distributions is an object for which a set of types of failures caused by factors independent of each other and described with separate mathematical models is considered.

The practical value of the proposed simulation model lies in the possibility of the forecasting of the future reliability of an object on the basis of the current knowledge of its selected properties and data on the conditions of its use. Referring to the groups of factors mentioned above, these may be:

- results of laboratory tests on the wear of the material, from which the object is to be made,

- data on the appearance (in the immediate area) of factors contributing to the occurrence of failures not associated with the wear processes.

It is therefore clear that the probability distributions of time to failure resulting from wear and random factors are treated differently in the adopted methodology. The probability distribution of wear failure is seen as a reliability model of changes in the object's technical state. Failure prediction is based on the knowledge of the tribological characteristics of the material from which the object is to be made and the allowable wear resulting from functional and design limitations. The probability distribution associated with random factors is understood as a model of the impact of the conditions of the object's use, which, affecting it in a specified way, leads to its failure (to some extent regardless of its design). 
The proposed simulation model does not allow for the effect of the object's design changes on its vulnerability to random factors induced failure to be included directly. It is, then, a simplification as the probability distribution obtained for some objects (of a given structure) is transferred onto a designed object (of a different structure), although its vulnerability to failure may be different. This indispensable and fundamental simplifying assumption can be justifiable in many cases, especially when minor changes are made in the structure of the designed object (compared with the objects examined earlier), and the random factors result in, inter alia, considerable permanent deformations, fractures (of some types), disruption of connections, other forms of disintegration and a substantial change of the technical state.

\section{Simulation-based calculation model}

For the assessment of the reliability of objects described with a number of probability distributions, following the assumptions presented in section 2, a simulation-based calculation model was developed. The model is based on the assumption that a system consists of elements operating in a koon structure. The reliability state of the system is determined entirely by the reliability states of the elements, so the system can be in the state of either availability or unavailability.

a)

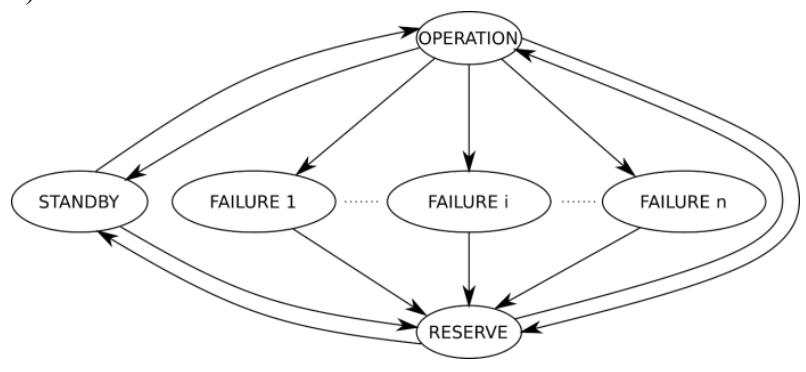

b)

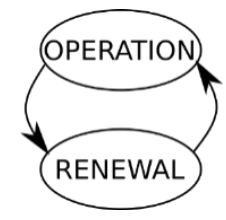

Fig. 1. A general graph of elements' operation-reliability states (a) and a graph of a system's reliability states (b)

In fig. 1a, a general graph of changes in operation-reliability states for an element is presented. Its essential state is operation. As a result of the failure caused by an $i$-th cause, the element transits to the state of $i$-th failure. In this state, it can either be repaired or continue working (depending on the adopted assumptions - e.g. if the failure is merely an exceedance of a nominal limit level of wear, which does not cause an incorrect work of the element). In the former case, the element is considered unavailable and sent to repair. In the latter case, the failure is detected during regular diagnostics of the system, which leads to the renewal of the failed elements. After the renewal, the element is shifted to reserve. The 
standby state is the operation-reliability state determined by the state of the other elements. It may occur when the given element is not affected by the failure, while the system is in the state of unavailability and is not operating. Fig. 1b illustrates the probable reliability states of the whole system.

The simulation procedure (sampling of times to failure of elements, assessment of the reliability of the entire system) follows the developed model presented in [7].

\section{A practical example}

Current collectors are devices, which are used for mechanical and flexible connecting of the contact wire with the electric system of the current supplied vehicle. The investigated AKP 4E current collector is composed of four arms, the upper ones of which are connected with cross-bars. The proper contact with the contact wire is provided by a set of springs. The current collector is driven pneumatically. It is connected with the overhead contact line system by means of a collector's head equipped with a carbon contact plate that enables the proper friction interaction. On its sides, the head is curved downwards - these parts prevent the collector from catching on the overhead wire, protecting it from being torn off.

A number of the failures of current collectors are the failures of the contact plates of the collector's head. Although it is small, its technical state often decides of the entire collector, and sometimes even the overhead contact line system, fulfilling its function. Failures of such important elements create problems for trains movements - frequently making it impossible for several hours, generating considerable inconvenience and financial loss.

The decisions taken during the design, manufacturing, operation and maintenance processes may significantly affect the wear rate and occurrence of failures of contact plates. This problem was presented in details in [10]. A large number of wear forms, failures resulting from material wear and unforeseen, random situations make the analysis of current collector contact plate failures a complex issue, which is extremely important for the safety and its proper functioning.

The data on the times to replacement of sets of current collector contact plates were collected in the operation process of several dozen electric locomotives EU07 series, which were equipped with AKP 4E current collectors. The collected data concern the contact plates used in the locomotives running on the area of Poland in various seasons of the year. For statistical purposes, using Statistica 13.1 software, tests of the goodness of fit of the time to renewal due to wear with various theoretical probability distributions were performed. The best fit, after Kolmogorov-Smirnov test and $\chi^{2}$ test, was obtained for 3-parameter Weibull distribution. The results of tests performed at the statistical significance of $\alpha=0,05$ do not give a ground for the rejection of the null hypothesis of empirical data fitness with this distribution. The obtained result is also confirmed by the obtained high p-values of the test $\left(0,980\right.$ in K-S test, and 0,785 in $\chi^{2}$ test). Probability density function and values of the estimated parameters of 3-parameter Weibull distribution: 


$$
f(t)=\alpha\left(\frac{1}{\beta}\right)^{\alpha} \cdot(t-\theta)^{\alpha-1} \cdot \exp \left(-\left(\frac{t-\theta}{\beta}\right)^{\alpha}\right)
$$

where:

$\beta=17,007 \cdot 10^{3}[\mathrm{~km}]-$ scale parameter,

$\alpha=1,361-$ parameter of shape,

$\theta=10 \cdot 10^{3}[\mathrm{~km}]$ - location parameter.

The expected operation time to the renewal of the set of contact plates:

$$
E(t)=\Gamma\left(1+\frac{1}{\alpha}\right) \cdot \beta+\theta
$$

in the analyzed case will be $25580 \mathrm{~km}$.

It was assumed that the fitting probability distribution of the time to replacement holds for reaching the limit state due to the reduction of the thickness of the current collector contact plate since it was determined on the basis of measurement and control cards of the plates wear rate. Apart from this, in the contact plates operation process there occur, unrecorded by the analyzed measurement cards, random events that also cause their failures, or result in the necessity for the plates to be taken out of operation. Such cases resulting from failures include the plate becoming detached from the support strip, part of the material scaling off, the plate partly burnt, or cracked and having to be replaced as an effect of the failure of the entire collector after it was broken down. On the basis of the available data on the frequency of the occurrence of such cases, the probability exponential distribution of contact plate's operation time to such occurrence with the density function and the parameter of failure rate was adopted:

$$
f(t)=\lambda \cdot e^{-\alpha \cdot t}
$$

where:

$\lambda=6,94 \cdot 10^{-6}[1 / \mathrm{km}]$.

The assessed probability distributions will be used in the simulation calculation model of the reliability of contact plates as objects described with a number of independent probability distributions of time to failure.

For the assessment of the reliability of a sets of contact plates of 1 out of 2 structure the following assumptions were adopted for the simulation calculations:

1) the locomotive is equipped with two current collectors which constitute a 1 out of 2 reliability structure,

2) each current collector is equipped with a set of contact plates,

3) for technological reasons (change of running direction) the collectors, and so the sets of contact plates operate alternately $400 \mathrm{~km}$ mileage each,

4) the inspection including the evaluation of the technical state of contact plates is performed every $12000 \mathrm{~km}$ of locomotive mileage, 
5) the limit allowable contact plate wear (reduction of its thickness) is calculated generously so that reaching it while the locomotive is running does not interrupt the locomotive's movement, and the replacement can be done only during the scheduled inspection,

6) the current collector's failure due to the impact of random factors, however, immobilizes it and involves the use of the redundant collector,

7) the failed collector is repaired after $400 \mathrm{~km}$ mileage, which should correspond to the locomotive reaching its destination,

8) the cases of exceeding the limit wear is described by 3-parameter Weibull distribution presented and the random factors induced failures are described with the exponential distribution mentioned,

9) during the simulation, the following is recorded: the moments of failure and replacement of individual contacts plates in the simulation horizon time, moments of failure of sets of collectors, the number of plate's replacements and a plate's mileage time to replacement since the limit wear has been exceeded.

In the assessment of the reliability of a single set of contact plates (of 1 out of 1 structure), the above assumptions are not applicable, except for point 8 . Reaching the limit wear is treated as a set failure resulting in the same effect as a random event cause failure (immediate interruption of the object's operation). In this simulation, plate's times to failure of any type are recorded. The other simulation parameters that are adopted: simulation time horizon $\left(T_{h}\right)$ equal to $3000000 \mathrm{~km}$, mileage discretization $(\Delta t)$ equal to $50 \mathrm{~km}$, number of simulation repetitions (n) equal to 5000 , Weibull distribution location parameter $(\theta$, three variants considered) 5000, 10000 and $20000 \mathrm{~km}$.

For the analyzed case, the general graph from Fig. 1a) has been appropriately modified to illustrate the real operation process of the current collector as closely as possible, which is shown in fig. 2.

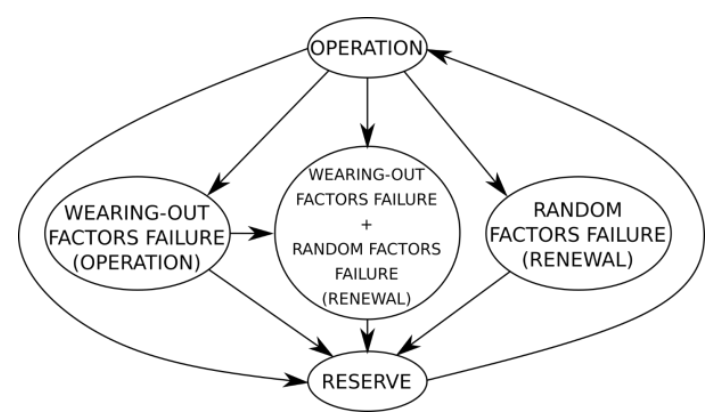

Fig. 2. Modified graph of contact plates operation and maintenance process

Based on the simulation results, reliability curves for the case of structure 1 out of 2 corresponding to the current collector's system (sets of contact plates) on the locomotive and case 1 out of 1 corresponding to a set of plates of a single collector were plotted, which is shown in figs. $3 \mathrm{a}$ and $3 \mathrm{~b}$. 
Figure $3 \mathrm{~b}$ illustrates the curves of the reliability function of a single set of contact plates for three different Weibull distributions of different location parameter, which illustrates the impact of a material type on the plate durability. This type of change of durability is to reflect a change of the property of the material or the original (initial) thickness of the contact plate.

a)

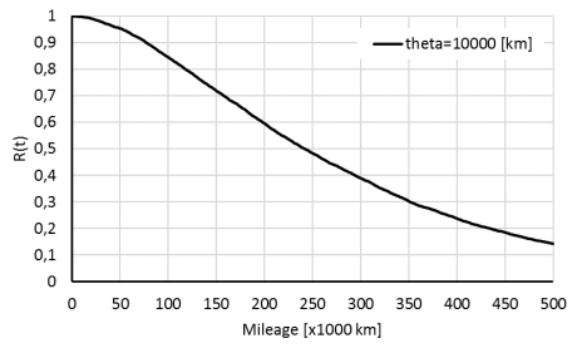

b)

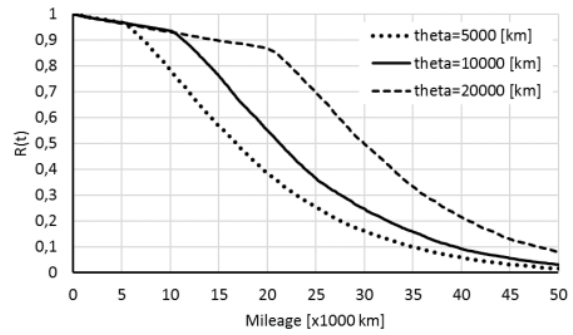

Fig. 3. Reliability function for 1 out of 2 structure $(\theta=10000[\mathrm{~km}])-\mathrm{a}$, and reliability function for 1 out of 1 structure for three location parameters $\theta$ in Weibull distribution $-b$

It is clear that a system of two sets of contact plates on the locomotive enables to produce reliability functions, which are significantly higher and last over a longer period of time than a set of plates of a single collector (fig. 3a). Moreover, a change of the location parameter in Weibull distribution, illustrating changes of the durability of a single set of plates, also considerably affects its reliability (fig. 3b). In the simulation experiment, it was also possible to record in particular simulations the number of the cases of exceeding the limit thickness of the plate (cf. assumptions 4 and 5), which is presented in fig. 4.

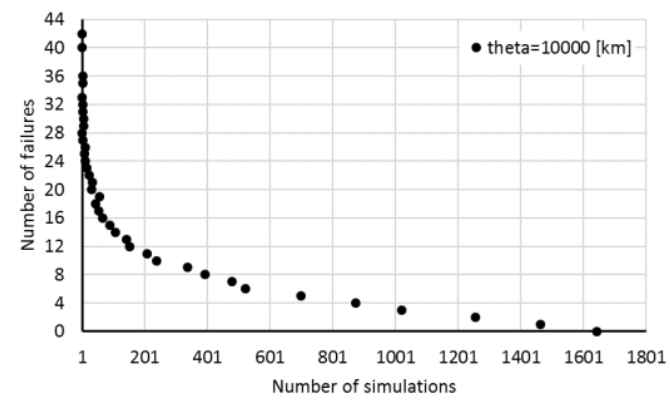

Fig. 4. Number of failures due to exceeding the limit wear in the system of two collectors $(\theta=10000 \mathrm{~km})$

Figure 5 illustrates the number of failures that occurred in the simulations due to exceeding the limit thickness of the set of plates using Weibull distribution with the same parameters of shape and scale but with the different location parameter $\theta$. In fig. 5a, a case of a slower material wear rate and parameter of location $\theta$ of $20000 \mathrm{~km}$ is shown, while 
fig. $5 \mathrm{~b}$ illustrates a case of material wear rate faster compared with the analyzed one and parameter of location $\theta$ of $5000 \mathrm{~km}$.

a)

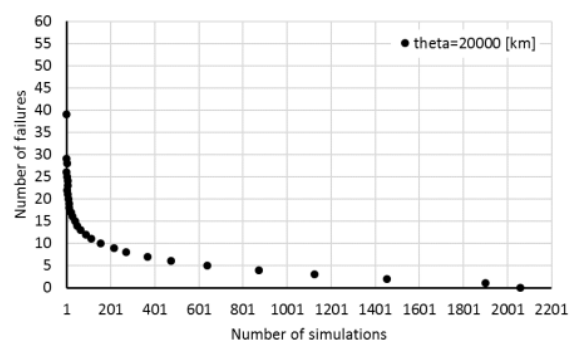

b)

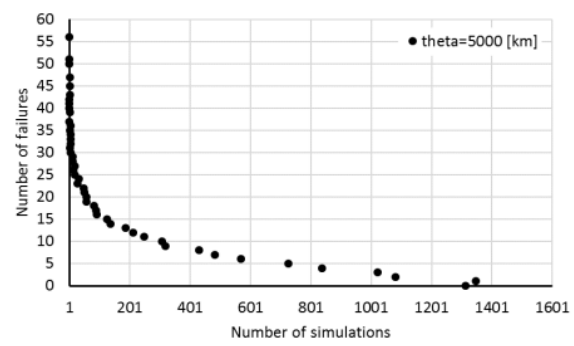

Fig. 5. Number of failures due to exceeding the limit wear in the system of two collectors: $\theta=20000$ $[\mathrm{km}]-\mathrm{a}, \theta=5000[\mathrm{~km}]-\mathrm{b}$

It can be clearly seen that when the material is of better quality or the plate is thicker (larger location parameter $\theta$ ), the case when an overworn plate continues to operate is definitely much less frequent. The condition for this to take place, however, might be the length of the adopted finite time horizon of the simulation $\left(T_{h}\right)$ which affects the number of the sets of plates (of a specified durability) used over the entire simulation.

\section{Conclusions}

The proposed simulation model enables, according to the assumptions, the forecasting of the reliability of technical objects described with a number of probability distributions of time to failure. It can be a useful tool for the designers of such objects and users interested in the modernization of their technical objects or only adaptations in their selected structural nodes.

The results of the simulation calculations indicate that for the analyzed sets of current collector contact plates a change of their durability (in the simulation introduced through the location parameter in the distribution of time to failure due to operation factors) affects the reliability of these plates. This might be one of the ways of profiling their operational reliability.

Further research employing the proposed simulation model may concern an analysis and selection of inspection and repair of objects in order to reduce the number of their failures prior to scheduled inspections. In the case of the analyzed contact plates, this would involve a reduction of the period of time during which an overworn plate (i.e. one that exceeded the limit wear) continues to be used. 


\section{Acknowledgement}

The research was performed in the framework of a research program done at the AGH University of Science and Technology in Cracow, at the Faculty of Mechanical Engineering and Robotics, the contract number - subsidy 16.16.130.942.

\section{References}

1. Andrzejczak K., Młyńczak M., Selech J.: Poisson-distributed failures in the predicting of the cost of corrective maintenance. Eksploatacja i Niezawodnosc - Maintenance and Reliability, 20 (4), 2018.

2. Fishman G.S.: Symulacja komputerowa. Pojęcia i metody. PWE, Warszawa 1981.

3. Judek S., Jarzębowicz L.: Stanowisko do skanowania 3D nakładek odbieraków prądu lokomotyw. Academic Journals Poznan University of Technology: Electrical Engineering, No. 75, 2013.

4. Judek S., Karwowski K., Mizan M., Wilk A.: Modelowanie współpracy odbieraka prądu z siecią trakcyjną. Przegląd Elektrotechniczny, No. 11, 2015.

5. Konieczny J.: Podstawy eksploatacji urządzeń. Wydawnictwo Ministerstwa Obrony Narodowej, Warszawa 1975.

6. Migdalski J. (ed.): Poradnik niezawodności: Podstawy matematyczne. Wydawnictwa Przemysłu Maszynowego „WEMA”, Warszawa 1982.

7. Młynarski S., Pilch R., Smolnik M., Szybka J., Wiązania G.: A concept of reliability assessment simulation model using systems structural decomposition. Journal of KONBiN, Vol. 46, 2018, DOI 10.2478/jok-2018-0023.

8. Młynarski S., Pilch R., Smolnik M., Szybka J., Wiązania G.: A method for rapid evaluation of k-out-of-n systems reliability. Eksploatacja i Niezawodnosc Maintenance and Reliability, 21(1), 2019.

9. Niewczas A., Rymarz J., Dębicka E.: Stages of operating vehicles with respect to operational efficiency using city buses as an example. Eksploatacja i NiezawodnoscMaintenance and Reliability, 21(1), 2019.

10. Sitarz M., Adamiec A., Mańka A.: Uszkodzenia węglowych nakładek stykowych pantografów kolejowych stosowanych w Polsce. TTS Technika Transportu Szynowego, 23(1-2), 2016.

11. Sitarz M., Hełka A., Mańka A., Adamiec A.: Badania dopuszczeniowe i eksploatacyjne odbieraków prądu. Przegląd Komunikacyjny, No. 7-8, 2012.

12. Sowa A.: Ocena stanu technicznego pojazdów szynowych na podstawie cech zdeterminowanych. PK im. Tadeusza Kościuszki, Kraków 2013.

13. Tyszer J.: Symulacja cyfrowa. WNT, Warszawa 1990.

14. Zarządzenie Nr 1/2010 Zarządu PKP Polskie Linie Kolejowe S.A. z dnia 18 stycznia 2010 r., Załącznik: Wymagania dla materiałów węglowych nakładek ślizgowych pantografów dopuszczonych do współpracy z siecią trakcyjną zarządzaną przez PKP Polskie Linie Kolejowe S.A. 


\section{SYMULACYJNE PROGNOZOWANIE NIEZAWODNOŚCI UKLADÓW O ELEMENTACH OPISYWANYCH WIELOMA ROZKLADAMI PRAWDOPODOBIEŃSTWA USZKODZEŃ}

\section{Wprowadzenie}

Poprawna praca obiektów technicznych w warunkach rzeczywistej eksploatacji zależy od ich niezawodności i trwałości. Właściwości te konstytuowane są na etapie projektowania i w istotny sposób wpływają na przebieg procesu eksploatacji, jej koszty i efektywność, co na przykładzie różnych obiektów analizowano m.in. w [1,9]. Modernizacja obiektów technicznych przez wprowadzenie zmian konstrukcyjnych i materiałowych zmienia ich niezawodność i trwałość. W niniejszym artykule przedstawiono model symulacyjny umożliwiający prognozowanie niezawodności i trwałości obiektów technicznych po ich modernizacji.

W badaniach laboratoryjnych można ocenić trwałość węzłów konstrukcyjnych np. po wprowadzeniu nowych materiałów, z których wykonane są elementy badanych węzłów. Ważna jest prognoza, jak wprowadzone zmiany wpłyną na niezawodność tych elementów w warunkach rzeczywistej eksploatacji.

W przypadku modernizowanych obiektów, dla których znane są rozkłady prawdopodobieństwa czasu pracy do uszkodzenia będącego skutkiem np. procesów zużycia (wyznaczane w badaniach laboratoryjnych) lub oddziaływania czynników losowych (w warunkach eksploatacyjnych), prognoza niezawodności może być przeprowadzona z wykorzystaniem symulacji komputerowej [2, 13], a w szczególnych przypadkach obliczeń analitycznych [8]. Wartość zmiennej losowej, jaką jest czas pracy do uszkodzenia obiektu, może być wtedy wyznaczana jako najmniejsza wartość spośród czasów uzyskanych ze wszystkich rozkładów opisujących możliwe rodzaje jego uszkodzeń. Podstawowym założeniem jest tu niezależność uszkodzeń obiektu ze względu na wyróżnione czynniki.

Przykładem obiektów, do których można zastosować tego rodzaju model, są nakładki ślizgowe odbieraków prądu pojazdów szynowych. W trakcie eksploatacji podlegają one różnego rodzaju czynnikom wymuszającym, co przekłada się na różne rodzaje ich uszkodzeń $[10,11]$. Jednocześnie ich poprawna praca jest ważna ze względu na zapewnienie ciągłości ruchu pojazdu szynowego. Jako istotne elementy, nakładki ślizgowe są poddawane cyklicznym kontrolom w celu określenia ich stanu technicznego [3, 12], 
a materiały zastosowane do ich konstrukcji muszą spełniać określone wymagania i przejść odpowiednie badania $[4,11,14]$.

W artykule zastosowano opracowany model do symulacyjnego prognozowania niezawodności układów o elementach opisywanych wieloma rozkładami prawdopodobieństwa uszkodzeń do wyznaczenia niezawodności zestawów nakładek ślizgowych eksploatowanych w wybranych pojazdach szynowych.

\section{Charakterystyka badanych obiektów technicznych}

Każdy obiekt techniczny podlega różnym czynnikom wynikającym z warunków jego eksploatacji. W konsekwencji czas pracy do uszkodzenia obiektu uzależniony jest od jego cech - nadanych mu w procesach projektowania i wytwarzania - oraz od warunków związanych z jego użytkowaniem i obsługiwaniem. Gdy proces występowania uszkodzeń nie jest opisywany modelem zakładającym ścisły determinizm, tradycyjnie czas pracy do uszkodzenia charakteryzuje się rozkładem jego prawdopodobieństwa. Rozkład ten dotyczy zatem zdarzeń stanowiących skutki oddziaływania ogółu wymienionych wcześniej czynników. Staje się on wówczas użytecznym narzędziem prognostycznym, pozwalającym (przynajmniej na pewnym poziomie analiz) na ograniczenie szczegółowych badań procesów fizyko-chemicznych czy organizacyjnych prowadzących do awarii rozpatrywanych obiektów (por. [5]). Podejście takie jest znane i wykorzystywane w budowie i eksploatacji maszyn od przynajmniej kilkudziesięciu lat (por. [6]).

Proponowany w niniejszym artykule niezawodnościowy opis obiektu technicznego za pomocą większej liczby rozkładów prawdopodobieństwa ma w założeniu umożliwiać prognozowanie niezawodności obiektu na etapie jego projektowania albo modernizacji. Działanie takie sprowadza się w praktyce do wykorzystania narzędzi symulacji komputerowej czasu pracy do uszkodzenia. Najistotniejszą cechą opracowanego modelu (oraz programu komputerowego) jest uwzględnienie w procesie symulacji kilku, określanych przez badacza, rozkładów prawdopodobieństwa, które opisują występowanie uszkodzeń na skutek oddziaływania różnego rodzaju czynników. Zakłada się, że oddziaływania te mają charakter niezależny od siebie, a skutki każdego z nich opisywane są odrębnym rozkładem prawdopodobieństwa. Przykładowo, tak wyodrębnione grupy czynników mogą stanowić:

- czynniki związane z procesami zużycia (opisywane rozkładem prawdopodobieństwa trwałości obiektu ze względu na zużycie),

- czynniki losowe (opisywane rozkładem prawdopodobieństwa czasu pracy do uszkodzenia obiektu niezwiązanego z procesami zużycia).

Wymienione czynniki losowe mogą być rozróżniane w zależności od ich charakteru i opisywane różnymi rozkładami prawdopodobieństwa.

Prowadzona symulacja komputerowa w każdej iteracji pozwala zatem na wyznaczenie chwili uszkodzenia obiektu jako najwcześniejszego zdarzenia spośród wszystkich zdarzeń wylosowanych za pomocą poszczególnych rozkładów prawdopodobieństwa (w ramach danej iteracji). 
Wobec powyższego, obiekt opisywany wieloma rozkładami prawdopodobieństwa uszkodzeń to obiekt, dla którego rozważa się zbiór rodzajów uszkodzeń powodowanych czynnikami niezależnymi od siebie i opisywanymi odrębnymi modelami matematycznymi.

Praktyczna wartość opracowanego modelu symulacyjnego wynika z możliwości prognozowania przyszłej niezawodności obiektu na podstawie aktualnej znajomości jego wybranych cech oraz danych o warunkach jego eksploatacji. Odwołując się do wspomnianych wyżej grup czynników, mogą to być:

- wyniki badań laboratoryjnych zużycia materiału, z którego wytworzony ma zostać obiekt,

- dane na temat ujawniania się (w otoczeniu) czynników przyczyniających się do występowania uszkodzeń niezwiązanych z procesami zużycia.

Widać zatem, że rozkłady prawdopodobieństwa czasu pracy do uszkodzenia na skutek zużycia oraz czynników losowych traktowane są w przyjętej metodyce w odmienny sposób. Rozkład prawdopodobieństwa związany z procesem zużycia postrzegany jest jako niezawodnościowy model zmian stanu technicznego obiektu. Uszkodzenia prognozuje się tu w oparciu o znajomość elementów charakterystyki tribologicznej materiału, z którego obiekt ma zostać wytworzony, oraz dopuszczalnej wartości zużycia wynikającej z ograniczeń funkcjonalno-konstrukcyjnych. Rozkład prawdopodobieństwa związany z czynnikami losowymi rozumiany jest jako model oddziaływania warunków eksploatacji obiektu, które oddziałując na niego w określony sposób, doprowadzają do jego uszkodzeń (do pewnego stopnia bez względu na jego konstrukcję).

Proponowany model symulacyjny nie pozwala na bezpośrednie, proste uwzględnienie wpływu zmian w konstrukcji obiektu na jego podatność na uszkodzenia powodowane czynnikami losowymi. Jest to zatem uproszczenie, gdyż rozkład prawdopodobieństwa uzyskany dla jednych obiektów (o pewnej konstrukcji) przenoszony jest na obiekt projektowany (o innej konstrukcji), choć może mieć on inną podatność na uszkodzenia. To niezbędne i istotne założenie upraszczające może mieć w wielu przypadkach uzasadnienie - zwłaszcza gdy w konstrukcji projektowanego obiektu wprowadzane są niewielkie zmiany (w porównaniu $\mathrm{z}$ obiektami już przebadanymi), a czynniki losowe prowadzą np. do znacznych odkształceń trwałych, pęknięć (niektórych rodzajów), rozłączenia połączeń, innych form dezintegracji i zasadniczej zmiany stanu technicznego.

\section{Symulacyjny model obliczeniowy}

Do oceny niezawodności obiektów opisywanych wieloma rozkładami prawdopodobieństwa zgodnie z założeniami przedstawionymi w punkcie 2 opracowano symulacyjny model obliczeniowy. Opracowany model zakłada, że układ składa się z elementów pracujących w strukturze kzn. Stan niezawodnościowy układu jest determinowany wyłącznie stanem niezawodnościowym elementów i stąd układ może być zdatny bądź niezdatny. 
a)

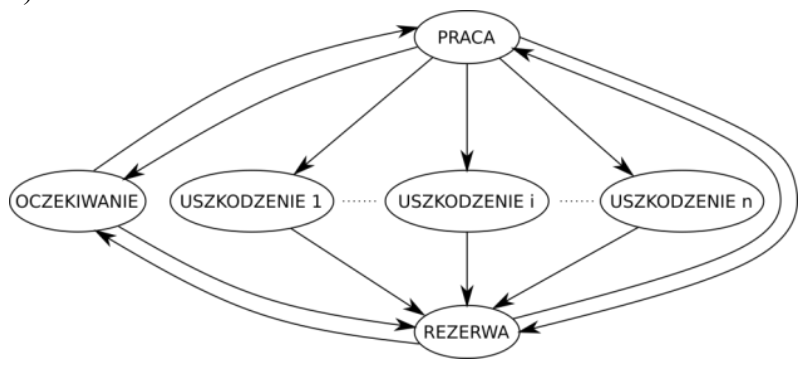

b)

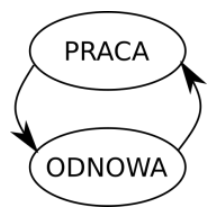

Rys. 1. Ogólny graf stanów niezawodnościowo-eksploatacyjnych elementu (a) oraz graf stanów niezawodnościowych układu (b)

Na rys. 1a przedstawiono ogólny graf zmian stanów eksploatacyjno-niezwodnościowych dla elementu. Podstawowym jego stanem jest praca. W wyniku uszkodzenia powstałego na skutek $i$-tej przyczyny, element przechodzi do stanu $i$-tego uszkodzenia. W tym stanie może on zostać odnowiony albo nadal pracować (w zależności od przyjętych założeń - jeżeli np. uszkodzenie jest tylko przekroczeniem umownego poziomu granicznego zużycia, co nie powoduje niepoprawnej pracy elementu). W pierwszym przypadku element jest uznawany za niezdatny i kierowany do odnowy. W drugim uszkodzenie jest wykrywane podczas cyklicznie wykonywanej diagnostyki układu, co prowadzi do odnowienia uszkodzonych elementów. Po odnowieniu element przechodzi do rezerwy. Stan oczekiwania jest stanem eksploatacyjno-niezawodnościowym zależnym od stanu innych elementów. Może wystąpić w sytuacji, kiedy dany element nie uległ uszkodzeniu, a układ jest w stanie niezdatności i nie pracuje. Na rys. 1b przedstawiono możliwe stany niezawodnościowe układu.

Procedura symulacyjna (losowanie czasów pracy do uszkodzenia elementów, ocena niezawodności całego układu) przebiega zgodnie z modelem opracowanym i przedstawionym w pracy [7].

\section{Przyklad praktyczny}

Odbieraki prądu służą do mechanicznego, ruchomego połączenia przewodu jezdnego z układem elektrycznym zasilanego pojazdu. Odbierak prądu AKP 4E, który jest przedmiotem badania, składa się $\mathrm{z}$ czterech ramion, $\mathrm{z}$ których górne połączone są poprzeczkami. Właściwy docisk do przewodu jezdnego zapewnia zespół sprężyn. Odbierak prądu napędzany jest pneumatycznie. Z siecią trakcyjną połączony jest za pomocą ślizgacza, wyposażonego w węglową nakładkę, umożliwiającą właściwą współpracę cierną. Ślizgacz po obu stronach wygięty jest ku dołowi - części te, zapobiegają zahaczeniu odbieraka o sieć trakcyjną, chroniąc ją przed ewentualnym zerwaniem. 
Szereg uszkodzeń odbieraków prądu to uszkodzenia nakładek stykowych ślizgacza. Choć to niewielki element, od jego stanu technicznego zależy często działanie całego pantografu, a niekiedy również sieci trakcyjnej. Uszkadzanie się tak istotnych obiektów jest problematyczne z punktu widzenia możliwości prowadzenia ruchu pociągów - nierzadko uniemożliwia go przez wiele godzin, generując duże utrudnienia oraz straty finansowe.

Decyzje podejmowane na etapie projektowania, wytwarzania oraz eksploatacji moga mieć istotny wpływ na szybkość zużycia oraz powstawanie uszkodzeń nakładek stykowych, co szczegółowo przedstawiono w [10]. Wielość form zużycia, uszkodzeń związanych ze zmęczeniem materiału oraz nieprzewidzianymi, losowymi sytuacjami sprawia, że analiza uszkodzeń nakładek odbieraków prądu to zagadnienie złożone, ale również bardzo istotne z punktu widzenia bezpieczeństwa oraz zapewnienia możliwości ich poprawnej pracy.

Dane dotyczące czasów pracy do wymiany zestawów nakładek odbieraka prądu zostały zgromadzone w procesie eksploatacji kilkudziesięciu lokomotyw elektrycznych serii EU07, w których wykorzystywane były odbieraki prądu typu AKP 4E. Zebrane dane dotyczą nakładek eksploatowanych w lokomotywach poruszających się na terenie Polski $\mathrm{w}$ różnych porach roku. W zakresie opracowania statystycznego zebranych danych, z wykorzystaniem oprogramowania Statistica 13.1, przeprowadzono testy zgodności czasów pracy do wymiany na skutek zużycia z różnymi teoretycznymi rozkładami prawdopodobieństwa. Najlepsze dopasowanie, według testu Kołmogorowa-Smirnowa oraz testu $\chi^{2}$, uzyskano dla rozkładu Weibulla przesuniętego. Wyniki przeprowadzonych na poziomie istotności $\alpha=0,05$ testów nie wykazały podstaw do odrzucenia hipotezy zerowej o zgodności danych empirycznych z tym rozkładem. Uzyskany wynik potwierdzają również otrzymane duże wartości współczynnika jakim jest p-wartość z testu $(0,980$ w teście K-S oraz 0,785 w teście $\chi^{2}$ ). Funkcja gęstości i wartości oszacowanych parametrów rozkładu Weibulla przesuniętego:

$$
f(t)=\alpha\left(\frac{1}{\beta}\right)^{\alpha} \cdot(t-\theta)^{\alpha-1} \cdot \exp \left(-\left(\frac{t-\theta}{\beta}\right)^{\alpha}\right)
$$

gdzie:

$\beta=17,007 \cdot 10^{3}[\mathrm{~km}]-$ parametr skali,

$\alpha=1,361-$ parametr kształtu,

$\theta=10 \cdot 10^{3}[\mathrm{~km}]-$ parametr przesunięcia.

Wartość oczekiwana czasu pracy do wymiany zestawu nakładek:

$$
E(t)=\Gamma\left(1+\frac{1}{\alpha}\right) \cdot \beta+\theta
$$

w analizowanym przypadku wyniesie 25,58 tys. $\mathrm{km}$.

Przyjęto, że dopasowany rozkład prawdopodobieństwa czasu pracy do wymiany dotyczy osiągnięcia umownego stanu granicznego ze względu na zmniejszenie grubości nakładki stykowej odbieraka, gdyż podstawą jego wyznaczenia były kontrolne karty pomiarowe stopnia zużycia nakładek. Niezależnie od tego w procesie eksploatacji nakładek 
występują jednak, nieodnotowywane w analizowanych kartach pomiarowych, losowe zdarzenia powodujące uszkodzenia nakładek lub konieczność ich wycofania z eksploatacji. Są to uszkodzenia w wyniku odspojenia nakładki od listwy wsporczej, wyłuszczenia części materiału, nadpalenia nakładki, pęknięcia na skutek uderzeń, a także uszkodzenia całego odbieraka np. na skutek jego wyłamania. Na podstawie dostępnych informacji o częstości występowania tego rodzaju przypadków przyjęto wykładniczy rozkład prawdopodobieństwa czasu pracy nakładki do ich wystąpienia z funkcją gęstości i parametrem intensywności uszkodzeń:

$$
f(t)=\lambda \cdot e^{-\alpha \cdot t}
$$

gdzie:

$\lambda=6,94 \cdot 10^{-6}[1 / \mathrm{km}]$.

Oszacowane rozkłady prawdopodobieństwa zostaną wykorzystane w symulacyjnym modelu obliczeniowym niezawodności zestawów nakładek stykowych jako obiektów opisanych wieloma niezależnymi rozkładami prawdopodobieństwa czasu pracy do uszkodzenia.

W przypadku szacowania niezawodności układu zestawów nakładek o strukturze 1 z 2 do obliczeń symulacyjnych przyjęto następujące założenia:

1) lokomotywa wyposażona jest w dwa odbieraki prądu, które stanowią strukturę niezawodnościową typu $1 \mathrm{z} 2$,

2) każdy odbierak wyposażony jest w jeden zestaw nakładek ślizgowych,

3) ze względów technologicznych (zmiana kierunku jazdy), odbieraki prądu, a tym samym zestawy nakładek, pracują wymiennie po $400 \mathrm{~km}$ przebiegu,

4) przegląd obejmujący ocenę stanu technicznego nakładek przeprowadzany jest co $12000 \mathrm{~km}$ przebiegu lokomotywy,

5) granica umownego dopuszczalnego zużycia zestawu nakładek (zmniejszenia grubości) dobrana jest $\mathrm{z}$ nadmiarem tak, że jej osiągnięcie $\mathrm{w}$ czasie jazdy nie powoduje przerwania ruchu lokomotywy, a wymiana może zostać przeprowadzana tylko w trakcie planowego przeglądu,

6) uszkodzenie odbieraka na skutek oddziaływania czynników losowych natychmiast uniemożliwia jego dalszą pracę i wiąże się z uruchomieniem odbieraka rezerwowego,

7) uszkodzony odbierak jest odnawiany po osiągnięciu przebiegu $400 \mathrm{~km}$, co ma odpowiadać dotarciu lokomotywy do stacji docelowej,

8) występowanie przekroczeń granicy umownego dopuszczalnego zużycia jest opisane przedstawionym rozkładem przesuniętym Weibulla, a przypadki uszkodzeń na skutek oddziaływania czynników losowych wymienionym rozkładem wykładniczym,

9) w czasie symulacji rejestrowane są: chwile uszkodzeń i wymian poszczególnych nakładek w horyzoncie czasowym symulacji, chwile uszkodzeń układu odbieraków, 
liczba wymian nakładek oraz przebieg nakładki od przekroczenia umownej granicy zużycia do jej wymiany.

W przypadku szacowania niezawodności pojedynczego zestawu nakładek (układ o strukturze $1 \mathrm{z} 1$ ) powyższe założenia nie mają zastosowania $\mathrm{z}$ wyjątkiem punktu 8 . Osiągnięcie wartości umownego granicznego zużycia jest przyjmowane jako uszkodzenie nakładki zachodzące z takim samym skutkiem jak uszkodzenie spowodowane czynnikami losowymi (natychmiastowe przerwanie pracy obiektu). W przypadku tej symulacji rejestrowane są czasy pracy nakładki do wystąpienia uszkodzenia któregokolwiek rodzaju.

$\mathrm{W}$ analizowanym przykładzie ogólny graf $\mathrm{z}$ rys. 1a został odpowiednio zmodyfikowany, tak aby jak najlepiej odzwierciedlał rzeczywisty proces eksploatacji odbieraka (zestawu nakładek ślizgowych), co przedstawiono na rys. 2. Pozostałe parametry symulacji przyjęto: horyzont czasowy symulacji (Th) równy $3 \mathrm{mln} \mathrm{km}$, dyskretyzację przebiegu $(\Delta \mathrm{t})$ równą $50 \mathrm{~km}$, liczbę powtórzeń symulacji $(\mathrm{n})-5000$, parametr przesunięcia rozkładu Weibulla ( $\theta$, trzy warianty) 5,10 i 20 tys. km.

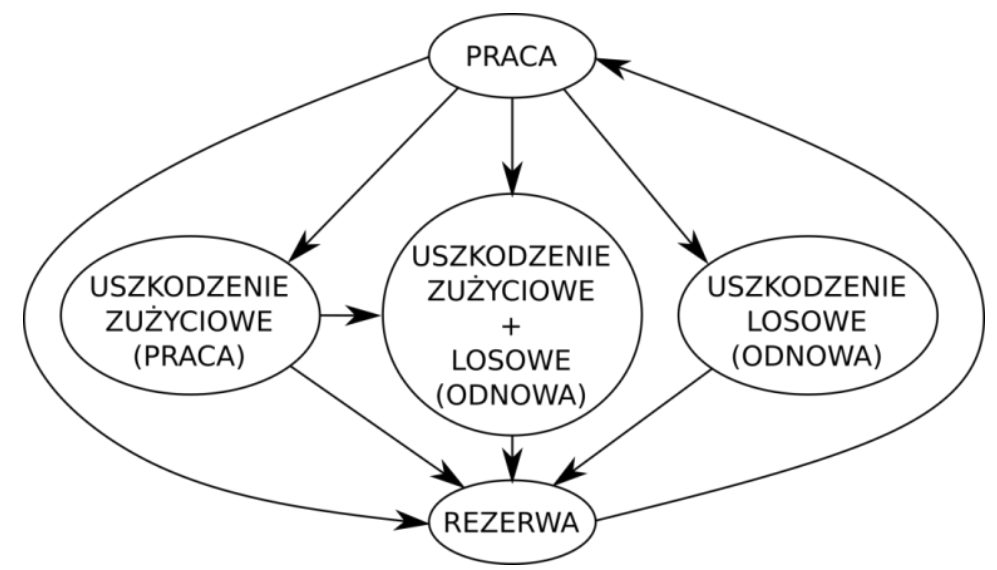

Rys. 2. Zmodyfikowany graf procesu eksploatacji nakładek

Na podstawie wyników symulacji uzyskano przebiegi niezawodności dla przypadku układu $1 \mathrm{z}$ 2, odpowiadającego układowi odbieraków (zestawów nakładek) na lokomotywie, oraz przypadku 1 z 1 odpowiadającemu zestawowi nakładek jednego odbieraka (rys. 3a i 3b).

$\mathrm{Na}$ rys. 3b pokazano przebiegi funkcji niezawodności pojedynczego zestawu nakładek dla trzech różnych rozkładów Weibulla różniących się parametrem przesunięcia, co ma obrazować wpływ wybranego rodzaju materiału na trwałość nakładki. Tego typu zmiana trwałości odzwierciedlać ma zmianę własności materiału lub bazowej grubości nakładki ślizgacza. 
a)

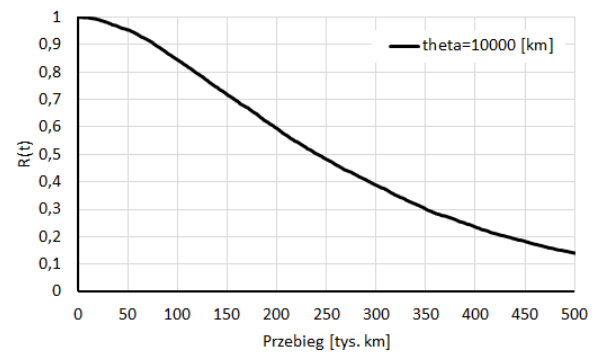

b)

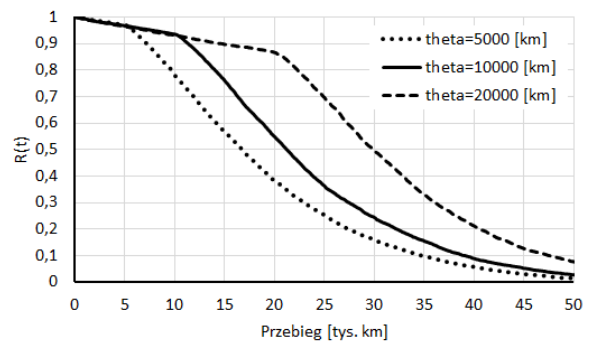

Rys. 3. Przebieg funkcji niezawodności dla układu $1 \mathrm{z} \mathrm{2,} \theta=10000 \mathrm{~km}$ (a), przebieg funkcji niezawodności dla przypadku $1 \mathrm{z} 1$, dla trzech wartości parametru przesunięcia $\theta$ w rozkładzie Weibulla (b)

Można łatwo zauważyć, że układ dwóch zestawów nakładek na lokomotywie pozwala uzyskiwać znacznie większe i utrzymujące się w dłuższym czasie wartości niezawodności niż w przypadku zestawu nakładek pojedynczego odbieraka (rys. 3a). Ponadto zmiana parametru przesunięcia w rozkładzie Weibulla obrazująca zmiany trwałości pojedynczego zestawu nakładek znacząco wpływa na jego niezawodność (rys. 3b). Przeprowadzony eksperyment symulacyjny pozwalał również rejestrować w poszczególnych symulacjach liczby przekroczeń umownej granicznej wartości grubości nakładki (por. założenia 4 i 5), co przedstawia rys. 4.

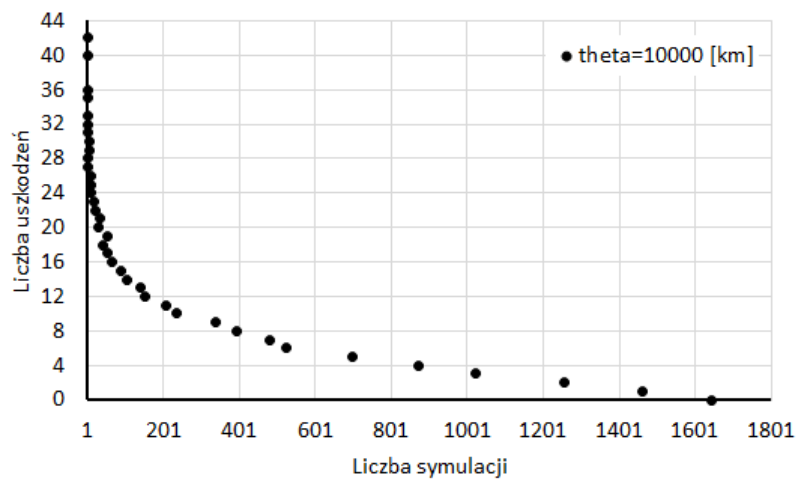

Rys. 4. Liczba uszkodzeń na skutek przekroczenia granicy zużycia w układzie dwóch odbieraków $(\theta=10000 \mathrm{~km})$

Na rys. 5 przedstawiono liczby uszkodzeń, które wystąpiły w symulacjach na skutek przekroczenia umownej granicznej wartości grubości zestawu nakładek z wykorzystaniem rozkładu Weibulla, z tymi samymi parametrami kształtu i skali, ale z innym parametrem przesunięcia $\theta$. Rys. 5a przedstawia przypadek, gdyby materiał zużywał się wolniej i parametr przesunięcia $\theta$ wynosił $20000 \mathrm{~km}$, a na rys. 5b - gdyby zużywał się szybciej w stosunku do badanego i parametr przesunięcia $\theta$ wynosił $5000 \mathrm{~km}$. 
a)

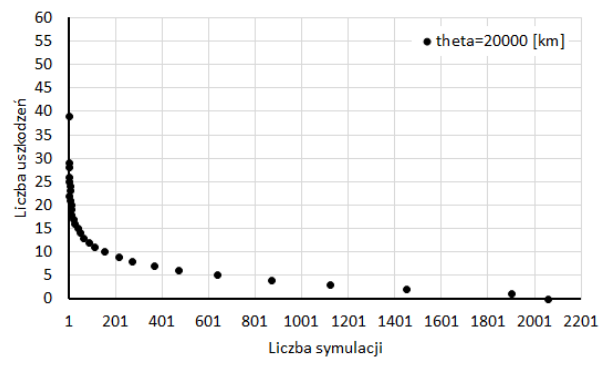

b)

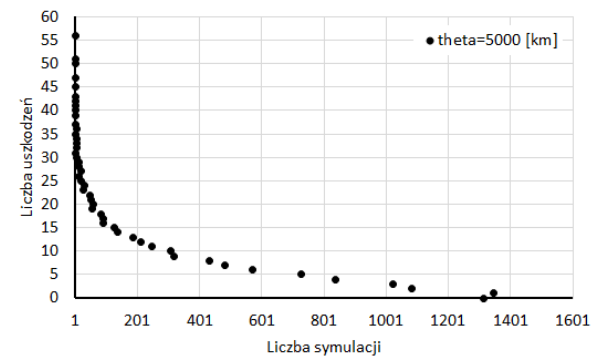

Rys. 5. Liczba uszkodzeń na skutek przekroczenia granicy zużycia zestawu nakładek w układzie dwóch odbieraków: $\theta=20000 \mathrm{~km}(\mathrm{a}), \theta=5000 \mathrm{~km}$ (b)

Można tu zaobserwować, że w przypadku lepszego materiału lub grubszej nakładki (większy parametr przesunięcia $\theta$ ) zdecydowanie rzadziej dochodzi do sytuacji, gdy nadmiernie zużyty zestaw nakładek wciąż pracuje. Uzyskane wartości mogą być jednak uwarunkowane przyjętą długością skończonego horyzontu czasowego symulacji $\left(\mathrm{T}_{\mathrm{h}}\right)$, który wpływa na liczbę zestawów nakładek (o określonej trwałości) wykorzystanych w czasie całej symulacji.

\section{Wnioski}

Opracowany model symulacyjny umożliwia zgodnie z założeniami prognozowanie niezawodności obiektów technicznych opisywanych wieloma rozkładami prawdopodobieństwa czasu pracy do uszkodzenia. Może on stanowić użyteczne narzędzie dla projektantów tego typu obiektów oraz dla eksploatatorów zainteresowanych modernizacją użytkowanych obiektów technicznych lub tylko zmianami w ich wybranych węzłach konstrukcyjnych.

Uzyskane wyniki obliczeń symulacyjnych wskazują, że w przypadku analizowanych układów nakładek ślizgowych odbieraków prądu, zmiana trwałości nakładek (wprowadzana w symulacji poprzez zmiany parametru przesunięcia w rozkładzie czasu pracy do uszkodzenia ze względu na czynniki związane ze zużyciem) ma wpływ na niezawodność zestawu nakładek i może to być jeden ze sposobów kształtowania ich niezawodności eksploatacyjnej.

Dalsze prace z wykorzystaniem opracowanego modelu symulacyjnego mogą dotyczyć analizy i doboru czasu przeprowadzania przeglądów i odnowy obiektów celem zmniejszenia liczby ich uszkodzeń występujących przed planowym przeglądem. W przypadku analizowanych nakładek ślizgowych wiązałoby się to ze zmniejszeniem czasu, w którym nadmiernie zużyta nakładka (tj. taka, która przekroczyła umowną granicę zużycia) jest nadal wykorzystywana. 


\section{Podziękowanie}

Prace wykonano $w$ ramach badań prowadzonych $w$ Akademii Górniczo-Hutniczej im. Stanisława Staszica w Krakowie, na Wydziale Inżynierii Mechanicznej i Robotyki, nr umowy - subwencja 16.16.130.942.

\section{Literatura}

1. Andrzejczak K., Młyńczak M., Selech J.: Poisson-distributed failures in the predicting of the cost of corrective maintenance. Eksploatacja i Niezawodnosc - Maintenance and Reliability, 20 (4), 2018.

2. Fishman G.S.: Symulacja komputerowa. Pojęcia i metody. PWE, Warszawa 1981.

3. Judek S., Jarzębowicz L.: Stanowisko do skanowania 3D nakładek odbieraków prądu lokomotyw. Academic Journals Poznan University of Technology: Electrical Engineering, No. 75, 2013.

4. Judek S., Karwowski K., Mizan M., Wilk A.: Modelowanie współpracy odbieraka prądu z siecią trakcyjną. Przegląd Elektrotechniczny, No. 11, 2015.

5. Konieczny J.: Podstawy eksploatacji urządzeń. Wydawnictwo Ministerstwa Obrony Narodowej, Warszawa 1975.

6. Migdalski J. (ed.): Poradnik niezawodności: Podstawy matematyczne. Wydawnic-twa Przemysłu Maszynowego „WEMA”, Warszawa 1982.

7. Młynarski S., Pilch R., Smolnik M., Szybka J., Wiązania G.: A concept of reliability assessment simulation model using systems structural decomposition. Journal of KONBiN, Vol. 46, 2018, DOI 10.2478/jok-2018-0023.

8. Młynarski S., Pilch R., Smolnik M., Szybka J., Wiązania G.: A method for rapid evaluation of k-out-of-n systems reliability. Eksploatacja i Niezawodnosc Maintenance and Reliability, 21(1), 2019.

9. Niewczas A., Rymarz J., Dębicka E.: Stages of operating vehicles with respect to operational efficiency using city buses as an example. Eksploatacja i Niezawodnosc Maintenance and Reliability, 21(1), 2019.

10. Sitarz M., Adamiec A., Mańka A.: Uszkodzenia węglowych nakładek stykowych pantografów kolejowych stosowanych w Polsce. TTS Technika Transportu Szynowego, 23(1-2), 2016.

11. Sitarz M., Hełka A., Mańka A., Adamiec A.: Badania dopuszczeniowe i eksploatacyjne odbieraków prądu. Przegląd Komunikacyjny, No. 7-8, 2012.

12. Sowa A.: Ocena stanu technicznego pojazdów szynowych na podstawie cech zdeterminowanych. PK im. Tadeusza Kościuszki, Kraków 2013.

13. Tyszer J.: Symulacja cyfrowa. WNT, Warszawa 1990.

14. Zarządzenie Nr 1/2010 Zarządu PKP Polskie Linie Kolejowe S.A. z dnia 18 stycznia 2010 r., Załącznik: Wymagania dla materiałów węglowych nakładek ślizgowych pantografów dopuszczonych do współpracy z siecią trakcyjną zarządzaną przez PKP Polskie Linie Kolejowe S.A. 